\title{
Contracteren in de platformeconomie
}

\author{
De derde-aanbieder als zwakke partij
}

Prof. dr. mr. V. Mak*

\begin{abstract}
1 Inleiding
Het contractenrecht is in beginsel gericht op gelijkwaardige contractspartijen en hanteert in uitzonderingsgevallen bijzondere regels om zwakkere partijen te beschermen. 'Zwakker' wordt in de context van het vermogensrecht gedefinieerd als economisch zwakker. Partijen die als zwakkere partij bescherming genieten, zijn bijvoorbeeld consumenten en werknemers. $Z_{i j}$ bevinden zich aan de afnamezijde van de markt en kunnen vaak niet of nauwelijks onderhandelen over de contractsvoorwaarden die de wederpartij bepaalt voor een transactie. Hun zwakte zit in een gebrek aan bargaining power, ofwel de capaciteit te onderhandelen, vaak afhankelijk van structurele ongelijkheden in de positie van consumenten ten opzichte van aanbieders en werknemers ten opzichte van werkgevers. ${ }^{1}$ Regelgeving beoogt hen te beschermen tegen onredelijk bezwarende bedingen of anderszins oneerlijke normen die sterkere contractspartijen hun opleggen. ${ }^{2}$ Professionele contractspartijen genieten dergelijke bescherming in beginsel niet, al worden kleine aanbieders bij uitzondering soms beschermd door reflexwerking van regels van consumentenbescherming. ${ }^{3}$
\end{abstract}

De driehoeksverhouding tussen aanbieders, consumenten en online platformen in de platformeconomie lijkt deze verdeling echter te doorbreken. Hoewel in de literatuur en in publieke debatten veel aandacht uitgaat naar de bescherming van consumenten in de platformeconomie, wordt in dit artikel betoogd dat de derde-aanbieder ${ }^{4}$ in deze constellatie mogelijk de zwakkere partij is. Hij moet aan de ene kant jegens consumenten voldoen aan wettelijke regels met betrekking tot consumentenbescherming, en aan de andere kant bindt de beheerder van het platform hem aan strikte servicenormen. Europese regelgeving biedt enige bescherming in de vorm van Verordening 2019/1150 (hierna ook: Verordening), ${ }^{5}$ maar de

* Prof. dr. mr. V. Mak is hoogleraar civiel recht aan de Universiteit Leiden.

1. J.G.J. Rinkes, De consument als zwakke partij, AA 2009, afl. 6, p. 380-387.

2. Art. 6:231 e.v. BW.

3. Over de reflexwerking van de grijze en zwarte lijst van onredelijk bezwarende bedingen (art. 6:236 en 6:237 BW) zie Asser/Sieburgh 6-III $2018 / 502$.

4. Ik hanteer deze terminologie omdat de aanbieder een derde is in verhouding tot de overeenkomst tussen consument en platform.

5. Verordening (EU) 2019/1150 ter bevordering van billijkheid en transparantie voor zakelijke gebruikers van onlinetussenhandelsdiensten, $\mathrm{PbEU}$ 2019, L 186/57. vraag is of dat voor de aanbieder voldoende is. Het recent gepubliceerde voorstel voor een Europese 'Digital Services Act' lijkt overigens aan deze Verordening weinig toe te voegen en richt zich eerder op bescherming van fundamentele rechten dan van economische rechten. ${ }^{6}$

Het artikel is als volgt opgebouwd. Paragraaf 2 schetst in grote lijnen de twee meest voorkomende bedrijfsmodellen in de platformeconomie en de positie van de derde-aanbieder in de driehoek aanbieder-consument-platform. Daarbij wordt besproken welke contractenrechtelijke regelgeving van toepassing is op de rechtsverhoudingen in die driehoek, ervan uitgaande dat de consument en de aanbieder zich in Nederland bevinden. Paragraaf 3 bespreekt de ongelijke positie van de aanbieder in verhouding tot het platform en welke bescherming het BW en Verordening 2019/1150 bieden voor de aanbieder als zwakkere partij. De vraag is echter of met die regelgeving voldoende bescherming gewaarborgd is. Om dat te bepalen volgt een analyse van de servicenormen die het grootste online verkoopplatform in Nederland, Bol.com, oplegt aan externe aanbieders. De servicenormen alsmede beschikbare gegevens over de naleving en handhaving ervan worden getoetst aan de bepalingen van de Verordening, aan art. 6:233 sub a BW, en aan de algemene norm van redelijkheid en billijkheid uit art. 6:248 lid 2 BW (par. 4). Paragraaf 5 maakt de balans op en concludeert dat derde-aanbieders in de platformeconomie structureel een zwakke positie hebben in hun contractuele verhouding tot grote platformen. Naast de bescherming van de consument zouden beleidsmakers in Nederland en in Europa zich ook hard moeten maken voor de bescherming van deze aanbieders via wettelijke regelgeving of private regulering.

\section{De positie van de aanbieder in de platformeconomie: twee modellen}

De meest voorkomende bedrijfsmodellen in de platformeconomie lijken in de basis op elkaar. Een aanbieder biedt via een online platform zijn producten of diensten aan en de consument kan via het platform het aanbod bekijken en een overeenkomst aangaan met de aanbieder. Tussen partijen

6. Europese Commissie, Proposal for a Regulation of the European Parliament and of the Council on a Single Market for Digital Services (Digital Services Act) and amending Directive 2000/31/EC, COM(2020)825 final. 
bestaan drie rechtsverhoudingen: tussen platform en aanbieder, tussen platform en consument, en tussen aanbieder en consument. In de laatste rechtsverhouding wordt de daadwerkelijke prestatie verricht, dat wil zeggen het leveren van een product of dienst.

Verschillen in de toepasselijke regels op de rechtsverhoudingen tussen partijen bestaan echter al naar gelang de aanbieder kwalificeert als een professionele of particuliere partij. Deze twee modellen moeten worden onderscheiden. Is de aanbieder een professionele handelaar, dan wordt een overeenkomst tussen hem en de consument gekwalificeerd als een b2c-overeenkomst waarop regels van consumentenkoop van toepassing zijn (art. 7:5 lid $6 \mathrm{BW}$ ) of andere regels van consumentenrecht. Voor consumentenovereenkomsten in algemene zin gelden bijvoorbeeld informatieverplichtingen op grond van de Richtlijn consumentenrechten (art. 6:230g lid 1 sub d BW) en kan in geval van misleiding een beroep worden gedaan op de regeling van oneerlijke handelspraktijken (art. 6:193a e.v. BW). Het gaat hier om regels van dwingend recht waarvan de aanbieder niet/nauwelijks ten nadele van de consument mag afwijken (art. 7:6 lid 1 en 2 en 6:230i lid 1 BW).

Is de handelaar een particulier, dan gelden tussen hem en de consument geen bijzondere regels van consumentenrecht. De overeenkomst moet in dat geval worden gekwalificeerd als een c2c- of peer-to-peerovereenkomst. De rechtsverhouding wordt beheerst door regels van algemeen verbintenissenrecht en eventueel door bijzondere regels uit Boek 7 en 7A BW als het gaat om koop, opdracht, huur of bruikleen.

De rechtsverhoudingen tussen het online platform en de gebruikers, de aanbieder en de consument, kunnen naargelang de omstandigheden worden gekwalificeerd als elektronische handel, bemiddeling, opdracht, lastgeving (in naam van de lastgever) of (als het platform ook zelf producten aanbiedt) als koop. De regels van algemeen verbintenissenrecht zijn eveneens van toepassing. Voor de rechtsverhouding die in dit artikel centraal staat, tussen platform en aanbieder, geldt dat de status van de aanbieder van belang is om te bepalen welke regels van toepassing zijn. Handelt de aanbieder beroeps- of bedrijfsmatig, dan moet de rechtsverhouding tussen platform en aanbieder worden gekwalificeerd als een b2c-verhouding en zijn regels van consumentenrecht van toepassing. Die regels zijn overigens in vrijwel alle gevallen van toepassing op de andere rechtsverhouding in de driehoek, die tussen het online platform en de consument. Handelt de aanbieder als particulier, dan zijn de regels van algemeen verbintenissenrecht uit Boek $6 \mathrm{BW}$ van toepassing en eventueel bijzondere regels uit Boek 7 en $7 \mathrm{~A}$ BW, maar niet de regels van consumentenrecht.

Interpretatieruimte bestaat nog bij de vraag wanneer een particuliere aanbieder verandert in een professionele handelaar. In de platformeconomie lijkt dat een redelijk veel voorkomend verschijnsel. De toegankelijkheid van online platformen geeft particulieren de mogelijkheid om kleinschalig producten en diensten aan te bieden. Indien een dergelijk handeltje succesvol begint te worden, kan het uitgroeien tot een bedrijfsmatige activiteit. Waar het omslagpunt ligt tussen particuliere en professionele handel is echter niet heel duidelijk en zal van geval tot geval moeten worden beoordeeld. Het Europees Hof van Justitie (HvJ EU) heeft in zaak C-105/17 (Kamenova) een aantal handvatten gegeven voor die beoordeling. ${ }^{7}$ Schaub meent terecht dat die handvatten zullen moeten worden beoordeeld in het licht van andere omstandigheden, waarbij bijvoorbeeld nevenactiviteiten die de hoofdactiviteit ondersteunen ook kunnen worden aangemerkt als bedrijfsmatig handelen, en waarbij de activiteiten als geheel moeten worden gewogen. ${ }^{8}$

De positie van de aanbieder in de rechtsverhouding met een online platform is daarmee op een aantal punten precair. Ten eerste kan een particuliere aanbieder op zeker moment de status van professionele handelaar krijgen en daardoor de bescherming van het consumentenrecht verliezen. Ten tweede zijn de algemene regels van ons verbintenissenrecht die van toepassing zijn op b2b-verhoudingen geschreven voor gevallen waarin beide partijen worden verondersteld gelijkwaardig te zijn. In de platformeconomie zal dat praktisch gezien echter vaak niet het geval zijn, in het bijzonder als sprake is van derde-aanbieders die hun waren verkopen op een platform waarop de platformbeheerder ook zelf actief is. Die verhouding kan als volgt worden omschreven.

\section{De ongelijke positie van de aanbieder in b2b- verhoudingen met platformen}

Aanbieders die via een online platform hun producten of diensten aanbieden, worden veelal door het platform aan bepaalde servicenormen gebonden. Voorbeelden zijn Amazon (servicevoorwaarden), ${ }^{9}$ Bol.com (servicenormen) ${ }^{10}$ en Airbnb (standaardvereisten of basisvereisten). ${ }^{11}$ Deze normen hebben als functie om de kwaliteit van de dienstverlening op het platform te waarborgen. Aanbieders bevinden zich in een 'take it or leave it'-positie en zullen de normen moeten accepteren indien zij via het platform hun producten of diensten willen aanbieden. Die positie kan op verschillende manieren tot ongelijkheid leiden in de relatie van platform en aanbieder. Ik licht twee punten uit: de status van servicenormen en de bescherming van aanbieders ten aanzien van de presentatie en

7. HvJ EU 4 oktober 2018, C-105/17, ECLI:EU:C:2018:808, RvdW 2019/385 (Kamenova).

8. M.Y. Schaub, Wie is handelaar?, TvC 2019, afl. 1, p. 5-13.

9. Amazon hanteert dezelfde servicevoorwaarden voor alle lokale websites: Amazon.com voor de Verenigde Staten, Amazon.de voor Duitsland, Amazon.fr voor Frankrijk, Amazon.es voor Spanje, Amazon.it voor Italië, Amazon.cn voor China, en Amazon.nl voor Nederland. De Engelstalige versie is de juridisch bindende versie. Voor de Nederlandstalige versie zie https://sellercentral.amazon.nl/gp/help/external/help.html? itemID $=201190440 \&$ language $=$ nl_NL\&ref $=$ efph_201190440_cont_2 (geraadpleegd op 30 november 2020).

10. Zie https://partnerplatform.bol.com/help/prestatie/servicenormen (geraadpleegd op 30 november 2020).

11. Zie www.airbnb.nl/help/article/576/wat-zijn-de-standaardvereistenvan-airbnb-voor-verhuurders (geraadpleegd op 30 november 2020). 


\section{Maandblad \\ Vermogensrecht}

inhoud van deze normen. Op beide punten heeft het online platform de regie in het bepalen van de tussen partijen geldende regels.

\subsection{De status van servicenormen}

De status van de door online platformen aan aanbieders opgelegde normen is niet altijd duidelijk. In sommige gevallen worden de regels weergegeven als algemene voorwaarden die deel zijn van de overeenkomst tussen platform en aanbieder, zoals bij Amazon en Bol.com, terwijl ze in andere gevallen als gedragscode lijken te worden gepresenteerd. Airbnb stelt bijvoorbeeld onder het kopje 'algemene voorwaarden' dat de daaronder genoemde 'voorwaarden, beleidsregels en normen' van toepassing zijn op de toegang tot en het gebruik van het Airbnb-platform door de aanbieder. ${ }^{12}$ De inhoud van de regels lijkt te suggereren dat het inderdaad om een mix gaat. Het non-discriminatiebeleid van het platform, opgenomen onder 'beleidsregels', is bijvoorbeeld algemeen aan de gemeenschap van Airbnb-gebruikers gericht en geldt voor alle gebruikers van het platform. Het zal eerder als gedragscode moeten worden gekwalificeerd. De vereisten voor aanbieders daarentegen leggen specifieke verplichtingen op aan aanbieders die rechtstreeks gerelateerd zijn aan de onderhandelingen over en de uitvoering van een via het platform gesloten overeenkomst. Deze bepalingen zullen eerder als algemene voorwaarden worden gezien.

De kwalificatie heeft gevolgen voor de rechtsbescherming van aanbieders ten opzichte van het platform. In geval van oneerlijke algemene voorwaarden kan een aanbieder een beroep doen op de bescherming die de norm van art. 6:233 sub a BW biedt tegen onredelijk bezwarende bedingen in algemene voorwaarden. Een dergelijk beding is vernietigbaar. Deze norm geldt ook in b2b-verhoudingen, enkele uitzonderingen daargelaten (zie art. 6:235 en 6:247 lid 2 BW). ${ }^{13}$ Gedragscodes worden minder snel als bindend gezien en tegen oneerlijke normen kan minder eenvoudig geageerd worden. Onder omstandigheden staat voor consumenten een beroep op de regeling van oneerlijke handelspraktijken open. Daarvoor is vereist dat een verplichting opgenomen in een gedragscode concreet en kenbaar is, en dat de handelaar heeft aangegeven dat hij aan de gedragscode gebonden is (art. 6:193c lid 2 sub b $\mathrm{BW}$ ). Een kleine aanbieder kan geen beroep doen op die regel. Ook wordt bij oneerlijke handelspraktijken reflexwerking van consumentenrecht ten behoeve van kleine aanbieders vrijwel stelselmatig afgewezen. ${ }^{14}$

12. Zie www.airbnb.nl/help/topic/250/algemene-voorwaarden (geraadpleegd op 30 november 2020).

13. L.M. van Bochove \& T.J. de Graaf, De discriminerende werking van de algemenevoorwaardenafdeling, MvV 2020, afl. 11, p. 386-391.

14. Vgl. Hof 's-Hertogenbosch 4 juli 2017, ECLI:NL:GHSHE:2017:3054; Hof Arnhem-Leeuwarden 14 juli 2020, ECLI:NL:GHARL:2020:5566.

\subsection{Transparantie en inhoudscontrole bij servicenormen}

Problematisch is dat de ongelijkheid die aanbieders op online platformen ondervinden van structurele aard is. Online platformen zijn vooral gericht op het aantrekken van consumenten en mikken daartoe op een zo hoog mogelijke klanttevredenheid, soms ten koste van kleine aanbieders die via het platform producten en diensten aanbieden. De vraag is welke wettelijke bescherming aanbieders kunnen inroepen, en of die bescherming voldoende is om het contractuele evenwicht tussen aanbieder en platform recht te trekken. Ik zet de regelgeving hier kort uiteen. De toets of die bescherming voldoende is, volgt in de volgende paragraaf.

De bescherming tegen oneerlijke bedingen in algemene voorwaarden, waarvan servicenormen voor aanbieders op online platformen een voorbeeld zijn, heeft twee aspecten: transparantie en een inhoudscontrole. In het BW zijn die twee aspecten voor b2b-overeenkomsten, anders dan bij consumentenovereenkomsten, niet afzonderlijk benoemd. ${ }^{15}$ De toetsing van servicenormen zal onder het Nederlandse recht dus vooral op de inhoud van de normen zien en niet zozeer op de vraag of ze duidelijk en begrijpelijk zijn geformuleerd.

Voor de inhoudscontrole staan twee wegen open. Ten eerste kan een beroep worden gedaan op de algemene norm van art. 6:233 sub a BW, op grond waarvan een onredelijk bezwarend beding in algemene voorwaarden kan worden vernietigd. De beoordeling zal voor ieder geval afhangen van de omstandigheden, waarbij een rol kan spelen hoe deskundig de wederpartij is waartegen de algemene voorwaarden zouden gelden. ${ }^{16}$ Daarnaast staat het partijen vrij om onder omstandigheden een beroep te doen op de algemene norm van redelijkheid en billijkheid uit art. 6:248 lid 2 BW. ${ }^{17}$ De beperkende werking van de redelijkheid en billijkheid kan een grond zijn voor het buiten toepassing laten van een beding, wanneer wordt vastgesteld dat het in stand houden van het beding in de gegeven omstandigheden naar maatstaven van redelijkheid en billijkheid onaanvaardbaar zou zijn (art. 6:248 lid 2 BW). De keuze tussen de twee routes kan afhangen van verschillen met betrekking tot de gevolgen van de sanctie, de mogelijkheid voor de rechter om ambtshalve rechtsgronden aan te vullen, en verjaringstermijnen. ${ }^{18}$

15. Vgl. art. 6:238 lid $2 \mathrm{BW}$ voor consumentenovereenkomsten.

16. M.B.M. Loos, Algemene voorwaarden (derde druk), Den Haag: Boom juridisch 2018, p. 159-161. Vgl. R.P.J.L. Tjittes, De hoedanigheid van contractspartijen. Een rechtsvergelijkend onderzoek naar de betekenis van de (onderlinge) hoedanigheid van partijen voor de totstandkoming en de vaststelling van de inhoud van rechtshandeling (diss. Groningen), Deventer: Kluwer 1994.

17. Zie Asser/Sieburgh 6-III 2018/485.

18. Zie in detail T.J. de Graaf, Exoneraties in (ICT-)contracten tussen professionele partijen, Deventer: Kluwer 2006, p. 9-10. Zie ook Asser/Sieburgh 6-III 2018/421-422 en 435. Cumulatie is niet mogelijk en het is aan de gerechtigde om een keuze te maken tussen de twee routes; zie HR 14 juni 2002, ECLI:NL:HR:2002:AE659, NJ 2003/112 m.nt. J. Hijma (Bramer/Colpro). 
Transparantie wordt wel expliciet geadresseerd door EUVerordening 2019/1150 inzake billijkheid en transparantie voor zakelijke gebruikers van onlinetussenhandelsdiensten (platform-to-business of p2b-Verordening). Inhoudelijk sluit de Verordening aan bij de bepalingen die voor het consumentenrecht zijn neergelegd in Richtlijn 1993/13/EEG inzake oneerlijke bedingen in consumentenovereenkomsten en Richtlijn 2005/29/EG inzake oneerlijke handelspraktijken. ${ }^{19}$ De Verordening is van toepassing op alle online platformen, ook indien ze niet gevestigd zijn in een EU-lidstaat, mits de zakelijke gebruiker van het platform en de consument beiden in de EU zijn gevestigd of woonachtig zijn (art. 1 lid 2 p2bVerordening). ${ }^{20}$ De $\mathrm{p} 2 \mathrm{~b}$-Verordening benoemt een aantal vereisten waaraan de algemene voorwaarden die online platformen ten opzichte van aanbieders hanteren, moeten voldoen. De voorwaarden moeten in duidelijke en begrijpelijke taal zijn opgesteld, eenvoudig beschikbaar zijn tijdens alle fasen van de commerciële verhouding tussen partijen inclusief de precontractuele fase, de redenen omvatten voor beslissingen tot opschorting of beëindiging van gebruikersaccounts van aanbieders op het online platform, informatie bevatten over aanvullende distributiekanalen waarvan aanbieders gebruik zouden kunnen maken, en algemene informatie bevatten over eigendom en controle van intellectuele-eigendomsrechten van zakelijke gebruikers (art. 3 lid 1 p2b-Verordening).

De sanctie op het niet-naleven van deze regels of van de opzegtermijn uit art. 3 lid 2 p2b-Verordening is nietigheid van de algemene voorwaarden of een specifiek beding (art. 3 lid 3 p2b-Verordening). Die sanctie lijkt stevig. Nietigheid treedt in Nederland, net als in veel andere lidstaten, van rechtswege in, terwijl de klassieke sanctie bij strijd met een dwingende wetsbepaling die strekt tot bescherming van een van de partijen (in dit geval de aanbieder) vernietigbaarheid is (art. 3:40 lid 2 BW) en op vernietigbaarheid door een van de partijen een beroep moet worden gedaan. ${ }^{21} \mathrm{Op}$ dat uitgangspunt wordt een uitzondering gemaakt voor b2c-overeenkomsten, nu het $\mathrm{HvJ}$ EU heeft beslist dat de nationale rechter gehouden is tot ambtshalve toetsing van oneerlijke bedingen, mits hij over voldoende feitelijke informatie beschikt. ${ }^{22}$ Wordt een beding na ambtshalve toetsing onredelijk bezwarend geacht, dan dient

19. Richtlijn 1993/13/EEG betreffende oneerlijke bedingen in consumentenovereenkomsten, PbEG 1993, L 95/29; Richtlijn 2005/29/ EG betreffende oneerlijke handelspraktijken van ondernemingen jegens consumenten op de interne markt, PbEU 2005, L 149/22.

20. Uitgezonderd zijn onlinebetalingsdiensten, onlinereclametools en onlinetussenhandelsdiensten voor de uitwisseling van reclame die niet gericht zijn op het faciliteren van het initiëren van directe transacties en die geen contractuele verhouding met consumenten bevatten (art. 1 lid 3 p2bVerordening).

21. Art. 3:50 lid $1 \mathrm{BW}$ voor de buitengerechtelijke vernietiging en art. 3:51 lid $1 \mathrm{BW}$ voor de rechterlijke vernietiging.

22. HvJ EU 27 juni 2000, C-240/98 t/m C-244/98, ECLI:EU:C:2000:346, NJ 2000/730 (Océano); HvJ EU 27 februari 2014, C-470/12, ECLI:EU:C:2014/101 (Pohotovost'). het ambtshalve te worden vernietigd, aldus de Hoge Raad. ${ }^{23}$ Voor b2c-overeenkomsten kan ambtshalve toetsing worden gerechtvaardigd doordat consumenten veelal geen beroep doen op vernietiging, bijvoorbeeld omdat zij niet bekend zijn met de mogelijkheid of vanwege hoge kosten van een procedure. $^{24} \mathrm{Bij}$ b2b-overeenkomsten gelden die overwegingen niet en wordt in beginsel uitgegaan van gelijkwaardigheid tussen partijen. Dat verschil is bijvoorbeeld duidelijk te zien in de recent aangenomen wetgeving in België, waar geldt dat de rechter niet ambtshalve de oneerlijkheid van bedingen toetst in b2b-verhoudingen, juist om ruimte te houden voor beoordeling en voor het mogelijk herstellen van het evenwicht tussen partijen. ${ }^{25}$ Het is dus opmerkelijk dat de Europese wetgever in de $\mathrm{p} 2 \mathrm{~b}-$ Verordening kiest voor nietigheid en niet, in navolging van art. 6 lid 1 van de Richtlijn oneerlijke bedingen in consumentenovereenkomsten, voor het 'onder de in het nationale recht geldende voorwaarden de consument [in dit geval de aanbieder; VM] niet binden' aan een oneerlijk beding, hetgeen we in het Nederlandse recht uiteindelijk vorm hebben gegeven als een ambtshalve toetsing met vernietiging.

Overigens kan de overeenkomst na vernietiging van een beding in stand blijven. Wordt een beding in een b2c-overeenkomst vernietigd en kan de overeenkomst niet zonder dat beding blijven bestaan, dan mag de rechter aanvullen. ${ }^{26}$ Ook bij b2b-overeenkomsten zal dat in geval van nietigheid van een beding het geval zijn. ${ }^{27}$

De Verordening biedt daarmee een aantal handvatten voor transparantie en eerlijke behandeling van aanbieders op een online platform. Omdat een grote variatie bestaat tussen de voorwaarden waaronder online platformen hun diensten aanbieden aan gebruikers, zijn de regels van de Verordening echter vrij summier. Twee inhoudelijke pijlers staan voorop: transparantie voor aanbieders op online platformen moet leiden tot eerlijke en voorspelbare handel, en grote online platformen moeten aanbieders toegang geven tot effectieve klachten- en geschillenbeslechting. ${ }^{28}$ Daarmee moet worden voorkomen dat online platformen onredelijke voorwaarden opleggen aan aanbieders, en dat ze eenzijdig, zonder

23. HR 13 september 2013, ECLI:NL:HR:2013:691, NJ 2014/274 (Heesakkers/Voets). Zie ook Asser/Sieburgh 6-III 2018/321; Loos 2018, p. 194; LOVCK\&T, Ambtshalve toetsing III, Den Haag: Raad voor de rechtspraak 2018.

24. HvJ EU 27 juni 2000, C-240/98 t/m C-244/98, ECLI:EU:C:2000:346, NJ 2000/730 (Océano), par. 26; HvJ EU 21 november 2002, C-473/00, ECLI:EU:C:2002:705, NJ 2003/703 (Cofidis/Fredout), par. 34; HvJ EU 4 juni 2009, C-243/08, ECLI:EU:C:2009:350, NJ 2009/395 (Pannon), par. 23 en 30 .

25. L. Korsten \& J. Movig, Belgische wetswijziging introduceert B2Bbescherming; een voorbeeld voor Nederland?, M\&M 2020, afl. 2, p. 68-76; J. Stuyck \& B. Keirsbilck, De nieuwe Belgische wet met betrekking tot misbruik van economische afhankelijkheid, onrechtmatige bedingen en oneerlijke marktpraktijken tussen ondernemingen: een eerste commentaar, SEW 2019, afl. 9, p. 374-394.

26. HvJ EU 30 april 2014, C-26/13, ECLI:EU:C:2014:282 (Kásler).

27. Vgl. p2b-Verordening, vooroverweging 20.

28. L.E. Felderhof \& M.P.C. Rozenbroek, Een gelijk speelveld in de online platformeconomie?, NtER 2019, afl. 5/6, p. 142-148. 
motivering, een aanbieder de toegang tot het platform ontzeggen. Of dat met deze regels bewerkstelligd gaat worden, valt echter nog te bezien. De praktijk kan weerbarstig zijn.

Ik noem hier ter illustratie de regel dat aanbieders bij eenzijdige wijziging van de algemene voorwaarden door het online platform de mogelijkheid moeten hebben tot opzegging (art. 3 lid 2 p2b-Verordening). De opzegtermijn moet ten minste vijftien dagen zijn en eventueel langer indien dit noodzakelijk is om aanbieders in staat te stellen technische of commerciële aanpassingen door te voeren om aan de gewijzigde voorwaarden te voldoen. De vraag is of aanbieders hiermee daadwerkelijk een opzegtermijn wordt geboden die 'redelijk' en 'evenredig' is (art. 3 lid 2 p2b-Verordening). De bepaling dat bij eenzijdige wijziging een opzegtermijn moet worden geboden, doet sterk denken aan de regel die voor b2c-overeenkomsten geldt, ${ }^{29}$ maar er is een wezenlijk verschil in bescherming. De machtsverhouding kan in bepaalde markten zodanig scheef zijn dat een kleine aanbieder reëel geen gebruik zal maken van de opzegmogelijkheid, omdat hij de toegang tot de markt verliest indien hij niet via het betreffende online platform handelt. ${ }^{30}$

De p2b-Verordening biedt niettemin een aantal waarborgen om transparantie van algemene voorwaarden te bewerkstelligen. Dat kan worden gezien als een welkome aanvulling op de inhoudscontrole volgend uit het BW, temeer omdat de inhoudscontrole in het BW aan beperkingen is onderworpen voor wat betreft met name de hoedanigheid en vestigingsplaats van de aanbieder (art. 6:235 en 6:247 lid 2 BW) en de p2b-Verordening die beperkingen niet kent. De vraag is dan of de regelgeving neergelegd in de algemenevoorwaardenregeling, art. 6:248 BW en de p2b-Verordening gezamenlijk voldoende bescherming bieden aan aanbieders op online platformen.

\section{Servicenormen: een kleine empirische studie}

Een analyse van de servicenormen van een online platform kan inzicht geven in het antwoord op die vraag. Het streven is niet om volledig te zijn, maar om aan de hand van een steekproef een beeld te krijgen van de positie van anbieders op online platformen. Als voorbeeld is gekozen voor Bol.com, als grootste online verkoopplatform in Nederland. Bol.com biedt zowel eigen producten aan als producten van externe aanbieders, waarbij de laatste categorie ruim 50\% van het aanbod omvat en blijft groeien. ${ }^{31}$ De focus in dit artikel is op de verkoop door externe aanbieders. Onderzocht wordt aan welke

29. Vgl. art. 6:237 sub c en 6:236 sub i BW, en Richtlijn 93/13/EEG, Annex I, punt 1 onder j, k en 1 .

30. Het mededingingsrecht zou dergelijke afhankelijkheidsrelaties kunnen aanpakken. Vgl. V.I. Daskalova, Oneerlijke platform-to-business-handelspraktijken: oude kwesties, nieuwe regelgeving, SEW 2018, afl. 12, p. 485-496. Zie ook Felderhof \& Rozenbroek 2019, p. 146. De Europese Commissie treedt reeds handhavend op tegen enkele grote online platformen, o.a. Apple; zie https://ec.europa.eu/commission/presscorner/ detail/en/ip_20_1073 (geraadpleegd op 18 december 2020).

31. Zie https://retailtrends.nl/news/59312/bol-com-nu-ook-in-omzetmeer-platform-dan-retailer (geraadpleegd op 18 december 2020). servicenormen aanbieders zich dienen te houden indien zij producten aanbieden via het platform. Vervolgens wordt geanalyseerd in hoeverre deze normen in overeenstemming zijn met het wettelijk kader bepaald door de p2b-Verordening, art. 6:233 sub a BW en de algemene norm van de redelijkheid en billijkheid uit art. 6:248 BW. Materieel worden de laatste twee normen als gelijk beoordeeld en ik zal ze om die reden gezamenlijk behandelen. ${ }^{32}$

Bol.com hanteert de volgende servicenormen voor zakelijke aanbieders, gemeten over specifieke periodes die ik hierna nader bespreek: ${ }^{33}$

- op tijd geleverd (bij 93\% van alle bestelde artikelen);

- annuleringen (tot $2 \%$ van de bestelde artikelen);

- track \& trace-nummer (bij alle pakketverzendingen);

- telefonische bereikbaarheid (bij 90\% van alle belpogingen);

- klantvragen (dynamische norm);

- beoordelingscijfer (een 8 of hoger);

- responstijd ( $90 \%$ binnen acht kantooruren behandeld);

- retouren (dynamische norm).

De inhoud van de servicenormen wordt verder gespecificeerd op de website, aangevuld met tips en rekenvoorbeelden. Voorop staat dat Bol.com streeft naar de beste service voor de klant (c.q. de consument) en dat de gestelde normen zowel gelden voor de derde-aanbieder als voor Bol.com zelf als aanbieder. De normen zijn dus bedoeld om bij te dragen aan het succes van Bol.com als platform in Nederland en België.

Bieden de servicenormen een redelijk evenwicht tussen de derde-aanbieder en het platform? Bekijken we eerst de transparantie van de normen, dan lijkt Bol.com te voldoen aan de vereisten van de p2b-Verordening. De servicenormen zijn in duidelijke en begrijpelijke taal opgesteld en ze zijn publiekelijk toegankelijk, dus eenvoudig beschikbaar tijdens alle fasen van de commerciële verhouding tussen partijen, inclusief de precontractuele fase. Ook de redenen voor opschorting of beëindiging van een verkopersaccount zijn duidelijk weergegeven op de website van Bol.com. ${ }^{34}$ Als aanvullende dienst biedt Bol.com, ook overzichtelijk weergegeven, de mogelijkheid om gebruik te maken van de logistieke organisatie van het platform. ${ }^{35}$

Een tweede toets is inhoudelijk: zijn dit nu redelijke verplichtingen om een derde-verkoper op het platform aan te houden? Om te bepalen of de servicenormen die toets kunnen doorstaan, zal moeten worden beoordeeld of zij niet onredelijk nadelig zijn voor de wederpartij in vergelijking met de

32. Vgl. De Graaf 2006, p. 10, met verwijzing naar Parl. Gesch. Boek 6 (Inv. 3, 5 en 6), p. 1620-1621 (MvA I Inv.).

33. Zie https://partnerplatform.bol.com/help/prestatie/servicenormen (geraadpleegd op 30 november 2020).

34. Zie https://partnerplatform.bol.com/nl/hulp-nodig/prestaties/ aangesproken-op-prestaties/ (geraadpleegd op 30 november 2020).

35. Zie https://partnerplatform.bol.com/nl/hulp-nodig/logistiek-via-bolcom/ (geraadpleegd op 30 november 2020). 
rechtsgevolgen die de overeenkomst zonder de bedingen zou hebben gehad. ${ }^{36}$ De toets is subjectief. Dat wil zeggen dat de nadeligheid van bedingen moet worden beoordeeld voor een concrete aanbieder en in het licht van alle omstandigheden van het geval. ${ }^{37}$ Uiteraard is het niet mogelijk die beoordeling op deze plaats voor een specifieke derde-verkoper op Bol.com te doen. Ik volsta met een aantal bespiegelingen die bij een concrete beoordeling een rol zullen spelen.

Indien enkel wordt gekeken naar de prestaties die deze aanbieders verschuldigd zijn aan consumenten die via Bol.com aankopen doen, dan zouden de bedingen de toets kunnen doorstaan. Deze aanbieders zijn, zoals alle aanbieders, verplicht regels van consumentenrecht en van algemeen contractenrecht na te leven. Het eerste vereiste in het rijtje van Bol.com, tijdige levering, zal in beginsel van de verkoper mogen worden verwacht. Tekortschieten op dit punt levert wanprestatie op (art. 7:9 en 7:19a lid $1 \mathrm{BW}$ ) en geeft de koper recht op schadevergoeding of ontbinding (art. 6:74 en 6:265 BW), voor zover het ging om een fatale termijn zelfs zonder ingebrekestelling (art. 7:19a lid 2 en 6:83 sub a BW). ${ }^{38}$

Deze redenering gaat echter voorbij aan de realiteit van de dagelijkse bedrijfsvoering van aanbieders. In de praktijk verloopt niet elke transactie volgens plan en zal het bijvoorbeeld niet in alle gevallen mogelijk zijn om producten tijdig te leveren. Aanbieders zullen daarom rekening houden met een zekere foutmarge in de nakoming van orders. Uiteraard hebben aanbieders een incentive om de foutmarge zo klein mogelijk te houden en gedupeerde klanten zo goed mogelijk een oplossing te bieden, bijvoorbeeld in de vorm van latere levering of terugbetaling van de aankoopprijs. Aanbieders zijn voor hun inkomsten immers afhankelijk van (tevreden) klanten. De vraag is daarom niet of een aanbieder aan alle wettelijke verplichtingen voldoet, maar welke foutmarge acceptabel is. In de verhouding tussen een platform en een derde-verkoper is dat eveneens de relevante vraag, waarbij overigens kan meewegen dat het streven naar een hoge klanttevredenheid met zich kan brengen dat de verwachtingen ten aanzien van verkopers hoger zijn dan bij een 'gewone' consumentenkoop die niet via Bol.com tot stand komt.

Terugkomend bij Bol.com is dan de vraag of de servicenormen geen onredelijk nadelige targets stellen voor de aanbieder. Van de servicenormen zijn er vier die metrische targets noemen: tijdige levering (93\%), annuleringen (maximaal 2\% van de bestelde artikelen), telefonische bereikbaarheid ( $90 \%$ van alle belpogingen) en responstijd ( $90 \%$ binnen acht kantooruren).

\footnotetext{
36. Loos 2018, p. 162.

37. HR 21 september 2012, ECLI:NL:HR:2012:BW6135, NJ 2013/431 (Van Marrum/Wolff). Kritisch over deze benadering: Loos 2018, p. 165. Ten gunste van enige objectivering zie ook C.M.D.S. Pavillon, Open normen in het Europees consumentenrecht: de oneerlijkheidsnorm in vergelijkend perspectief, Deventer: Kluwer 2011, p. 152.

38. Tenzij de aanbieder gebruik maakt van 'Logistiek van bol.com'; zie https://partnerplatform.bol.com/nl/hulp-nodig/prestaties/ servicenormen-bol-com/ (geraadpleegd op 30 november 2020).
}

Precieze gegevens over de meetmethoden van Bol.com zijn niet voor alle servicenormen te achterhalen op de website. Het volgende kan worden opgemerkt ten aanzien van wat wel te achterhalen valt. ${ }^{39}$

Hoewel gegevens over het gedrag van aanbieders op Bol.com en de respons van het platform voor een buitenstaander niet beschikbaar zijn, kan via online forums wel anekdotisch bewijs van onvrede onder aanbieders worden gevonden. Een aanbieder klaagt bijvoorbeeld dat de target die Bol.com oplegt voor annuleringen onredelijk hoog is. ${ }^{40}$ Uit zijn bericht is op te maken dat de target over twaalf weken gemeten wordt, wat betekent dat tegenover één annulering in die periode 49 succesvolle verkopen moeten staan. De aanbieder beklaagde zich erover dat die target onredelijk hoog is voor kleine aanbieders, in het bijzonder omdat zij veelal niet eens dat aantal verkopen halen. Daarmee zit het foutpercentage al snel boven de $2 \%$. Indien dit werkelijk de praktijk is van Bol.com, dan zou de target inderdaad onredelijk kunnen zijn voor deze verkoper. Dit voorbeeld laat zien dat de omstandigheden van het geval van groot belang zijn om te bepalen of een servicenorm onredelijk nadelig is. ${ }^{41}$ Wat voor de ene aanbieder nadelig is, hoeft dat voor de andere niet te zijn. Een grote aanbieder zal bijvoorbeeld minder snel moeite hebben met de annuleringsnorm van maximaal 2\%. Overigens is het mogelijk dat de voorwaarden van Bol.com gewijzigd zijn sinds dit voorval zich voordeed.

Bij de servicenorm 'op tijd geleverd' lijkt Bol.com wel aandacht te hebben voor kleine aanbieders. De target wordt wekelijks gemeten. Een verkoper krijgt een waarschuwing indien de weekscore lager is dan $93 \%$ bij drie of meer verlate artikelen. Bij een of twee verlate artikelen telt de score niet mee, omdat Bol.com een 'absolute ondergrens in aantallen' hanteert. Het zou de transparantie bevorderen als die aantallen op de website genoemd zouden worden. Uit eigen berekening leid ik af dat de score meetelt bij een minimum van 43 bestelde artikelen. ${ }^{42}$ Aanbieders die minder dan dit aantal bestellingen per week ontvangen, blijven dus uit de wind. De norm zou de toets van redelijkheid dus, behoudens andere omstandigheden, kunnen doorstaan.

Een vraag is of de norm nog steeds gerechtvaardigd is indien de aanbieder een natuurlijk persoon is die een eenmanszaak of een kleine onderneming runt. Ook een eenmanszaak kan binnen de definitie van handelaar, en daarmee onder het begrip 'zakelijke verkoper' van Bol.com vallen. Regels die van toepassing zijn op b2b-overeenkomsten zijn echter niet altijd voldoende toegesneden op dit soort kleine ondernemers. Om die reden wordt bijvoorbeeld in het Nederlandse recht soms

39. Vgl. voor Amazon V. Mak, Legal Pluralism in European Contract Law, Oxford: Oxford University Press 2020, hoofdstuk 7.

40. Zie www.klacht.nl/vervolg-dubieuze-accountblokkering-enverwijdering-van-het-totale-aanbod/ (laatst geraadpleegd op 30 november 2020).

41. Vgl. Asser/Sieburgh 6-III 2018/481; Loos 2018, p. 163-164.

42. Waarbij drie artikelen $7 \%$ uitmaken van de in een week bestelde artikelen. 
reflexwerking van de grijze en zwarte lijst voor onredelijk bezwarende bedingen aangenomen ter bescherming van kleine ondernemingen die zich in een zwakke onderhandelingspositie bevinden. ${ }^{43}$ Mogelijk kan een kleine onderneming op die grond een verweer vinden indien de in de servicenormen vastgelegde prestaties niet gehaald worden.

Bol.com zou in een dergelijk geval kunnen betogen dat het platform alleen aanbieders toelaat die voldoen aan haar (hoge) standaarden, en dat daarvoor vereist is dat de servicenormen worden nageleefd. Niet-naleving kan tot reputatieschade leiden voor het platform. ${ }^{44}$ Effectief zou dat betekenen dat kleine ondernemingen alleen toegang tot het platform hebben indien zij zich qua prestaties kunnen meten met grotere professionele aanbieders. Of dat een wenselijk resultaat is, is een vraag die niet kan worden beantwoord met een analyse van het huidige contractenrecht. Eerder zullen wetgever en beleidsmakers zich met die vraag moeten bezighouden.

\section{Conclusie}

Concluderend kan worden gezegd dat Bol.com strikte normen hanteert voor derde-aanbieders. Maar die strikte normen zijn niet in alle gevallen onredelijk nadelig voor aanbieders. Ze kunnen worden gerechtvaardigd doordat Bol.com een hoge kwaliteit van dienstverlening voor klanten nastreeft en aanbieders vooraf kunnen weten aan welke servicenormen zij moeten voldoen. De transparantie van die normen kan echter op sommige punten worden verbeterd, bijvoorbeeld in de weergave van de berekening voor weekscores. Verder laat de analyse hiervoor zien dat de servicenormen van Bol.com onder omstandigheden onredelijk nadelig kunnen zijn, in het bijzonder voor kleine aanbieders. De p2b-Verordening en de BWregels betreffende onredelijk bezwarende bedingen en de redelijkheid en billijkheid kunnen niet in alle gevallen voldoende bescherming bieden. Kleine aanbieders lopen om die reden het risico zich te binden aan voor hen onhaalbare targets, met als sanctie uitsluiting van het platform.

Voor wetgever en beleidsmakers kan deze constatering een aanleiding zijn om de bescherming van derde-aanbieders op online platformen tegen het licht te houden. Is regulering nodig om hun gelijkere kansen te geven in relatie tot platformen? Die vraag verdient minstens evenveel aandacht als de bescherming van consumenten in de platformeconomie.

43. Loos 2018, p. 330. Zie in bredere zin H.N. Schelhaas, Commerciële contractanten - consistenter differentiëren?, Den Haag: Boom juridisch 2018.

44. In die zin Rb. Midden-Nederland 4 maart 2016, ECLI:NL:RBMNE: 2016:1118 (Tresbizz BV/Bol.com BV). 